\title{
New records of Batrachochytrium dendrobatidis in Chilean frogs
}

\author{
J. Bourke ${ }^{1, *}$, T. Ohst ${ }^{2,3}$, Y. Gräser ${ }^{3}$, W. Böhme ${ }^{1}$, J. Plötner ${ }^{2}$ \\ ${ }^{1}$ Zoologisches Forschungsmuseum Alexander Koenig, Adenauerallee 160, 53113 Bonn, Germany \\ ${ }^{2}$ Museum für Naturkunde, Leibniz-Institut für Evolutions- und Biodiversitätsforschung an der Humboldt-Universität zu \\ Berlin, Invalidenstraße 43, 10115 Berlin, Germany \\ ${ }^{3}$ Institut für Mikrobiologie und Hygiene (Charité), Humboldt-Universität zu Berlin, Dorotheenstraße 96, 10117 Berlin, Germany
}

\begin{abstract}
We used molecular techniques to examine 11 species of frogs in 6 localities in southern Chile to ascertain the incidence of the chytrid fungus Batrachochytrium dendrobatidis $(B d)$. We detected the fungus in 2 localities (Coñaripe and Raúl Marín Balmaceda) in 3 species: Batrachyla leptopus, Pleurodema thaul and Rhinoderma darwinii. Our findings expand the list of Bd hosts to include $B$. leptopus and $P$. thaul and extend the spatial distribution in Chile to include the southernmost $B d$ record at Raúl Marín Balmaceda.
\end{abstract}

KEY WORDS: Batrachochytrium dendrobatidis $\cdot$ Chytridiomycosis $\cdot$ Amphibia $\cdot$ Anura $\cdot$ Chile

\section{INTRODUCTION}

Because of multiple variables, such as habitat loss, environmental pollution, introduction of non-native species, climate change and infectious diseases, amphibians are more often threatened with extinction than are birds and mammals (IUCN 2010). Chytridiomycosis is caused by the fungus Batrachochytrium dendrobatidis $(B d)$ (Longcore et al. 1999), which occurs on every continent (Rachowicz et al. 2005) and has been linked to amphibian declines (Stuart et al. 2004, Pounds et al. 2006)

Within Chilean fauna, amphibians have the highest percentage rate of threatened species (36.2\%) and the highest level of endemism (69\%). Chile ranks 11th worldwide in terms of endemism rates and 13th in terms of the percentage of Endangered or Extinct species (i.e. the percentage of the total number of amphibian species in the respective countries) (Stuart et al. 2008). Most amphibian species inhabit the rainy temperate forest in southern Chile, and this area accounts for the high level of endemism. However, the temperate forest is rapidly being destroyed by plantations of introduced species (Neira et al. 2002), causing biodiversity to suffer and many species to be threatened (Debinski \& Holt 2000, Watson et al. 2004).

Almost one-third of Chilean amphibian species are described as evolutionarily distinct and globally endangered (EDGE; www.edgeofexistence.org/species/ complete_search.php). Among the ecosystems of Chile, the temperate forest is considered a hotspot of biodiversity and conservation priority (Conservation International; www.biodiversityhotspots.org/xp/hotspots/ chilean_forests/ Pages/default.aspx). The Chilean temperate forest, however, also includes a region that is 1 of 11 in the New World thought to be optimal for the presence of $B d$ : the ecological conditions of this region coincide with the environmental conditions suitable for the fungus (Ron 2005, Rödder et al. 2010).

In Chile. $B d$ has been detected recently in the introduced frog species Xenopus laevis (Solis et al. 2010) and in the native species Rhinoderma darwinii (Bourke et al. 2010). In the present study, we obtained additional information on the distribution of $B d$ in Chile and on the species infected. 


\section{MATERIALS AND METHODS}

During the southern hemisphere summer between December 2009 and February 2010 we manually captured frogs from 6 populations from the temperate forest of Chile (Fig. 1). Frogs were swabbed for PCR detection of $B d$ and then released at the site of capture. We wiped a sterile cotton swab along the skin of captured frogs for $\sim 30 \mathrm{~s}$, focusing on forelimbs, hindlimbs and the pelvic region. DNA was extracted from swabs with DNeasy Blood \& Tissue Kits (Qiagen), following the extraction protocol of the manufacturer. Isolated DNA was preserved in Eppendorf microcentrifuge tubes containing $98 \%$ ethanol.

DNA of Batrachochytrium dendrobatidis was detected with a modified real-time (rt) TaqMan PCR assay (Boyle et al. 2004). In this assay the TaqMan probe was not conjugated with a minor groove binder but included locked nucleic acid (LNA, N+) bases to

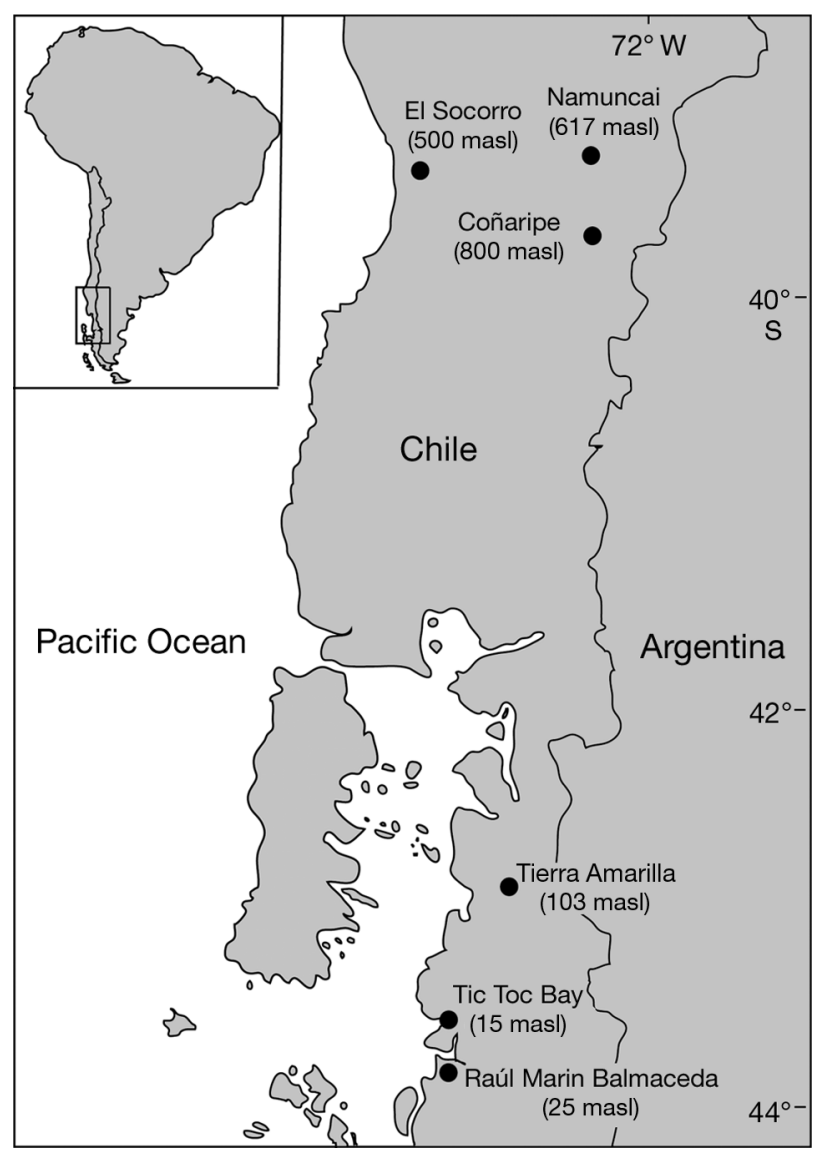

Fig. 1. Chilean frog populations analyzed for the presence of B. dendrobatidis: Raúl Marín Balmaceda $\left(43^{\circ} 47^{\prime} \mathrm{S}, 72^{\circ} 57^{\prime} \mathrm{W}\right)$; Tic Toc Bay $\left(43^{\circ} 36^{\prime} \mathrm{S}, 72^{\circ} 53^{\prime} \mathrm{W}\right)$; Tierra Amarilla $\left(43^{\circ} 00^{\prime} \mathrm{S}\right.$, $\left.72^{\circ} 29^{\prime} \mathrm{W}\right)$; El Socorro $\left(39^{\circ} 12^{\prime} \mathrm{S}, \quad 73^{\circ} 01^{\prime} \mathrm{W}\right)$; Namuncai $\left(39^{\circ} 11^{\prime} \mathrm{S}, 71^{\circ} 51^{\prime} \mathrm{W}\right)$; Coñaripe $\left(39^{\circ} 32^{\prime} \mathrm{S}, 71^{\circ} 55^{\prime} \mathrm{W}\right)$. masl: $\mathrm{m}$ above sea level. Inset shows location of study area in southern Chile elevate the melting temperature (5'-6FAM-CGA GTC+ G+AA+ C+A+A+ AAT-BBQ-3'). All rtPCR reactions were performed in a final volume of $20 \mu \mathrm{l}$ on a LightCycler 480 (Roche Applied Science). The reaction mixtures contained $0.25 \mu \mathrm{M}$ of each primer (ITS1-3 Chytr and 5.8S Chytr; Boyle et al. 2004), $62.5 \mu \mathrm{M}$ of each dNTP, $1.5 \mathrm{mM} \mathrm{MgCl}_{2}, 6 \% \mathrm{BSA}, 2 \mu \mathrm{l}$ of $10 \times$ reaction buffer (BD, Solis BioDyne), 1 unit Taq DNA polymerase (AmpliTaq, ABI) and $1 \mu \mathrm{l}$ DNA. The cycling profile consisted of an initial denaturation step at $96^{\circ} \mathrm{C}$ for $5 \mathrm{~min}$, followed by 50 cycles of $10 \mathrm{~s}$ at $96^{\circ} \mathrm{C}$ and $1 \mathrm{~min}$ at $60^{\circ} \mathrm{C}$. We included negative controls and a positive control for each amplification. rtPCR reactions were performed twice for each sample.

\section{RESULTS}

Of 79 amphibians tested, 9 (11.4\%) were infected with $B d$ : Batrachyla leptopus, $\mathrm{n}=2$ out of $11(2 / 11$, $18.2 \%)$; Pleurodema thaul, $\mathrm{n}=4 / 14(28.6 \%)$; Rhinoderma darwinii, $\mathrm{n}=3 / 6(50 \%)$. No infection was detected in Alsodes igneus ( $\mathrm{n}=2)$, Batrachlya antartica $(\mathrm{n}=1), B$. taeniata $(\mathrm{n}=2)$, Eupsophus calcaratus $(\mathrm{n}=$ $37), E$. vertebralis $(\mathrm{n}=3), E$. migueli $(\mathrm{n}=1)$, E. roseus $(\mathrm{n}=1)$ or E. emiliopugini $(\mathrm{n}=3)$, but, except for E. calcaratus, sample sizes were small. We detected chytrid infections only at Coñaripe $(\mathrm{n}=4 / 14,28.6 \%)$ and Raúl Marín Balmaceda $(n=5 / 14,35.7 \%)$.

\section{DISCUSSION}

Our findings expand the list of amphibian species susceptible to $B d$ and the distribution of infected species in Chile, including the most southern record of $B d$ at Raúl Marín Balmaceda. $B d$ was detected in Batrachyla leptopus and Pleurodema thaul for the first time during our survey, which adds to concerns about the threat of $B d$ to Chile's unique and endangered fauna.

The incidence of chytridiomycosis may vary seasonally from low to massive infections within a population, with infection rates usually being higher during cooler seasons (Woodhams \& Alford 2005, Woodhams et al. 2008). The low prevalence of infections in frogs and the high proportion of uninfected populations in the temperate forest of Chile may be a short-term phenomenon because we collected our samples exclusively during the southern hemisphere summer (January to February).

We have insufficient data to estimate the effect of $B d$ on amphibian diversity in Chile. Additional individuals, populations and species must be examined, and infected populations must be monitored to correlate the infection rate to population dynamics. Analysis of 
preserved collection material may provide information about the historical patterns of $B d$ occurrence in Chile.

Acknowledgements. We thank D. Guzman, E. Gonzales, L. Castro and M. Nonque (Pumalín), P. Camoglio and R. Calcagni (Namuncai) and G. Rebolledo (Universidad Católica de Temuco) for their help and land permits, and Thomas Uzzell (Philadelphia) for reviewing the English. F. Gómez and M. Sierra assisted in the field work. Scientific permits were provided by Servicio Agrícola Ganadero (SAG), Chile. This research was funded by Chester Zoo/North of England Zoological Society in collaboration with Leipzig Zoo, the Zoologische Gesellschaft für Arten- und Populationsschutz (ZGAP), Reptilia, and the Deutsche Forschungsgemeinschaft (grants PL 213/6-1 GR 1467/11-1). J.B. acknowledges a grant from DAAD-CONICYT.

\section{LITERATURE CITED}

Bourke J, Mutschmann F, Ohst T, Ulmer P and others (2010) Batrachochytrium dendrobatidis in Darwin's frog Rhinoderma spp. in Chile. Dis Aquat Org 92:217-221

Boyle DG, Boyle DB, Olsen V, Morgan JAT, Hyatt AD (2004) Rapid quantitative detection of chytridiomycosis (Batrachochytrium dendrobatidis) in amphibian samples using real-time Taqman PCR assay. Dis Aquat Org 60:141-148

Debinski D, Holt R (2000) A survey and overview of habitat fragmentation experiments. Conserv Biol 14:342-355

IUCN (International Union for Conservation of Nature and Natural Resources) (2010) 2010 IUCN Red List of Threatened Species. www.iucnredlist.org/documents/ summarystatistics/2011_1_RL_Stats_Table_4a.pdf (accessed 4 November 2010)

Longcore JE, Pessier AP, Nichols DK (1999) Batrachochytrium dendrobatidis gen. et sp. nov., a chytrid pathogenic to amphibians. Mycologia 91:219-227

Neira E, Verscheure H, Revenga C (2002) Chile's frontier

Editorial responsibility: Alex Hyatt,

Geelong, Victoria, Australia forests: conserving a global treasure. World Resources Institute, Comité nacional pro defensa de la fauna y flora, Austral University of Chile, Valdivia

> Pounds JA, Bustamante MR, Coloma LA, Consuegra JA and others (2006) Widespread amphibian extinctions from epidemic disease driven by global warming. Nature 439: 161-167

Rachowicz LJ, Hero J, Alford RA, Taylor JW and others (2005) The novel and endemic pathogen hypotheses: competing explanations for the origin of emerging infectious diseases of wildlife. Conserv Biol 19:1441-1448

Rödder D, Kielgast J, Lötters S (2010) Future potential distribution of the emerging amphibian chytrid fungus under anthropogenic climate change. Dis Aquat Org 92:201-207

Ron SR (2005) Predicting the distribution of the amphibian pathogen Batrachochytrium dendrobatidis in the New World. Biotropica 37:209-221

Solís R, Lobos G, Walker S, Fischer M, Bosch J (2010) Presence of Batrachochytrium dendrobatidis in feral populations of Xenopus laevis in Chile. Biol Invasions 12: $1641-1646$

> Stuart SN, Chanson JS, Cox NA, Young BE, Rodrigues ASL, Fischman DL, Waller RW (2004) Status and trends of amphibian declines and extinctions worldwide. Science 306:1783-1786

Stuart SN, Hoffman M, Chanson JS, Cox NA, Berridge RJ, Ramani P, Young BE (eds) (2008) Threatened amphibians of the world. Lynx Editions, Barcelona, IUCN, Gland and Conservation International, Arlington, VA

Watson J, Whittaker R, Dawson T (2004) Habitat structure and proximity to forest edge affect the abundance and distribution of forest-dependent birds in tropical coastal forests of southern Madagascar. Biol Conserv 120:311-327

$>$ Woodhams DC, Alford RA (2005) Ecology of chytridiomycosis in rainforest stream frog assemblages of tropical Queensland. Conserv Biol 19:1449-1459

Woodhams DC, Alford RA, Briggs CJ, Johnson M, RollinsSmith LA (2008) Life history trade-offs influence disease in changing climates: strategies of an amphibian pathogen. Ecology 89:1627-1639

Submitted: November 11, 2010; Accepted: April 27, 2011

Proofs received from author(s): June 29, 2011 